\title{
Caffeine degradation in water by gamma irradiation, ozonation and ozonation/gamma irradiation
}

\author{
Murat Torun, \\ Dinara Abbasova, \\ Dilek Şolpan, \\ Olgun Güven
}

\begin{abstract}
$\overline{\text { Abstract. Aqueous solutions of caffeine were treated with ozone and gamma irradiation. The amounts of remaining }}$ caffeine were determined after solid phase extraction as a function of absorbed dose and ozonation time. In addition to this, some important parameters such as inorganic ions, chemical oxygen demand (COD) dissolved oxygen and total acidity changes were followed. Caffeine $(50 \mathrm{ppm})$ is found to be completely decomposed at $3.0 \mathrm{kGy}$ and $1.2 \mathrm{kGy}$ doses in the absence of $\mathrm{H}_{2} \mathrm{O}_{2}$ and in $1.20 \mathrm{mM} \mathrm{H}_{2} \mathrm{O}_{2}$ solutions, respectively. In the case of gamma irradiation after ozonation, $50 \mathrm{ppm}$ caffeine was removed at $0.2 \mathrm{kGy}$ when the solution was ozonized for $100 \mathrm{~s}$ at a rate of $10 \mathrm{~g} \mathrm{O}_{3} \mathrm{~h}^{-1} \mathrm{in} 400 \mathrm{~mL}$ $50 \mathrm{ppm}$ paracetamol solution.
\end{abstract}

Key words: caffeine $\bullet$ effect of ozone $\bullet$ radiolytic decomposition $\bullet$ advanced oxidation process (AOPs) $\bullet$ caffeine decomposition $\bullet$ COD change

\author{
M. Torun ${ }^{\bowtie}$, D. Şolpan, O. Güven \\ Department of Chemistry, \\ Hacettepe University, \\ 06800 Beytepe, Ankara, Turkey, \\ Tel.: +90 312297 7988, Fax: +90 312299 2163, \\ E-mail: mtorun@hacettepe.edu.tr
}

\section{Abbasova}

Institute of Radiation Problems of Azerbaijan National

Academy of Science,

9 B. Vakhabzade Str., Baku, Azerbaijan

Received: 22 November 2013

Accepted: 5 February 2014

\section{Introduction}

Caffeine (3,7-dihydro-1,3,7-trimethyl-1H-purine-2,6-dione) is a natural purine compound and present in most drinks such as tea, coffee and cola nuts. The high consumption of these beverages focused most researchers on caffeine behaviour in aquatic media. Coffee and tea plants are the major sources of caffeine in which caffeine varies between 1 and $4 \%$ by weight $[1,2]$. Caffeine is also an environmental problem for soil and water supplies [3-5]. Coffee and tea pulps, obtained when processing of tea and coffee, are disposed to the soil and discharged into the ground and underground water sources. These pulps contain some nutritional compounds such as carbohydrates, proteins [6] and some anti-nutritional factors such as caffeine and polyphenols which decrease the quality of nutritional value of the coffee pulp [7]. Caffeine also affects the quality of sleep [8,9] and have negative affects on the health of the human beings reported in the literature. Caffeine decomposition is important for the health of the living organisms and environmental aspects because of its adverse effects. Conventional methods of caffeine removal are water decaffeination (caffeine is extracted to water then to solvent) solvent 
extraction and supercritical carbondioxide extraction [10]. Organic chlorinated solvents or mixtures of these solvents are used for the extraction of caffeine from water and pulps [11] but organic chlorinated solvents are also another problem for the environment if not used properly and discarded carefully. Solubility of caffeine in water is $1.992 \mathrm{~g} / 100 \mathrm{~mL}$ water at $24^{\circ} \mathrm{C}$ [12] relatively higher than most of the organic compounds and has to be removed from water.

Conventional water treatment methods include mechanical removal, filtration and activated sludge. These methods are not destructive technologies as irradiation treatment [13-17] for removal of some water soluble natural and industrial compounds like caffeine. Radiation technology has some advantages over the ones which are no radioactivity production during treatment, no waste, safe for personnel, environment and general public, economically competetive and with high efficiency. High-energy irradiation of water generates hydrated electrons $\left(\mathrm{e}_{\mathrm{aq}}^{-}\right)$, hydroxyl radicals $\left({ }^{\circ} \mathrm{OH}\right)$ and hydrogen radicals $\left(\mathrm{H}^{\circ}\right)$ in water that interact with a wide range of pollutants $[14,18]$. The interaction processes include decomposition of organic compounds, decolourization of dyes, redox reactions and other chemical reactions in addition to disinfection.

$\mathrm{OH}$ radical is the most powerful oxidant known to occur in water and hydrated electrons $\mathrm{e}_{\mathrm{aq}}^{-}$is the most powerful reductant formed during water radiolysis. Processes which generate hydroxyl free radicals to decompose pollutants effectively are referred as "Advanced Oxidation Processes" (AOPs) [19].

Ozone is also another powerful oxidizing agent which is used for drinking water and waste water treatment on a technical scale [20-23]. Decomposition of organic solutes with ozone follows two paths which are direct oxidation through the attack of ozone at the electron rich site of the solute and indirect oxidation that ozone produces hydroxyl radicals after radiolysis or photolysis. These radicals exhibit little solute selectivity and react very rapidly with organic and inorganic solutes.

When ozonized solution is exposed to high-energy radiation, the yield of hydroxyl free radicals is higher than each system alone because of two origins for hydroxyl free radicals, one of them is from water radiolysis and the other is from ozone decomposition during water radiolysis [13]. Some research groups studied and explained the reaction of ozone with radiolysis products of water [2, 20, 24-26].

Chemical oxygen demand (COD) is one of the important parameters for the aquatic environment. When it is not possible to detect the compounds and their amounts in aquatic samples, this method gives results about the degree of mineralization of organic wastes in waters.

Toxicity end points for aqueous solutions of caffeine were investigated with Ceriodaphnia dubia, Pimephales promelas and Charaxes dilutus by means of $48 \mathrm{~h} \mathrm{LC}_{50}$, 7-day $\mathrm{LC}_{50}$ and 7-day $\mathrm{LC}_{25}$ and reported as caffeine is not a threat for freshwater organisms with its current presence in the aquatic environment [27].

Radiolytic removal of caffeine is not being of interest in the literature with a great concern. In this study, caffeine, one of the most important natural and industrial pollutants is selected as a target compound because of its diverse effects on the human health and environment. To remove caffeine from water completely, irradiation and ozonation methods and their combinations are used. The main objective of this study is to examine the effect of gamma irradiation on the decomposition of aqueous caffeine and the synergic effects of hydrogen peroxide and preliminary ozonation of caffeine solutions. Hydrogen peroxide concentration was $1.20 \mathrm{mM}$ which is the optimum condition for effective degradation of $50 \mathrm{ppm}$ caffeine solution determined experimentally. Preliminary ozonized solutions were irradiated at $0.2 \mathrm{kGy}$ irradiation dose and the results were compared with only ozonized caffeine solutions. Irradiation dose was selected as $0.2 \mathrm{kGy}$ to examine the effect of gamma irradiation in the presence of ozone even if at low irradiation doses. The remaining caffeine and possible intermediates after treatment were observed with GC/MS and ion chromatography. Methyl ester of 2,4-DP is used as an internal standard for chromatographic quantitative analysis of caffeine. This novelty is useful for monitoring both 2,4-DP, which is a widely used herbicide still present in natural waters, after conversion of 2,4-DP to methyl ester (internal standard) and caffeine (a natural compound) in GC/MS conditions used.

\section{Experimental}

\section{Materials}

Caffeine, (from Aldrich, 99\% purity), 2,4-dichlorophenoxypropionic acid (2,4-DP) as internal standard after conversion to methyl ester, (from Aldrich, 95\% purity) were used without further purification. Stock standard solutions of caffeine and methyl ester of 2,4-DP were freshly prepared before injection and were mixed or diluted (if necessary) to prepare the adjusted amounts and stored in a refrigerator $\left(4^{\circ} \mathrm{C}\right)$. Solvents: n-hexane ( $95 \%$ purity), methanol ( $99.5 \%$ purity), acetone (99\%) were supplied from Merck. Dichloromethane, used as the solvent of caffeine were obtained from Fluka (99.9\%). For ion chromatography, possible acid standards oxalic acid dihydrate $(99 \%)$, acetic acid $(99.7 \%)$ and formic acid were obtained from Sigma-Aldrich and BDH, respectively. Nitrite and nitrate standards are from Dionex seven anion standard II. Sodium carbonate used as mobile phase for ion chromatography is obtained from Dionex, $0.5 \mathrm{M}$ sodium carbonate is diluted to $10 \mathrm{mM}$ with deionized water. The chemicals used in the tests of formaldehyde and total acid yield are, formaldehyde (37\%), acetylacetone (98\%), ammonium acetate (98\%), sodium hydroxide (97\%) which were obtained from Merck, BDH, Sigma-Aldrich and Merck, respectively. Hydrogen peroxide (35\%) is purchased from Riedel-de Haen. Chemicals for COD analysis are potassium dichromate $(\geq 99.5 \%)$, sulphuric acid (95-98\%), silver sulphate, mercury(II) sulphate $(\geq 99.0 \%)$ are from Merck, ammonium iron(II) sulphate hexahydrate (Mohr salt) is from Riedel de-Haen, the constituents of ferroin indicator; 1,10-phenanthroline $(\geq 99.5 \%)$ and iron(II) sulphate pentahydrate $(\geq 99 \%)$ are from Merck and Riedel de-Haen, respectively. Potassium hydrogen phthalate $(\geq 99.5 \%)$ standard as a COD analyte is from Merck. Potassium iodide 
$(99.6 \%)$ for peroxide tests is obtained from Sigma. Sodium chloride and sulphuric acid for Fricke dosimeter are supplied from Merck. All chemicals were used without any further purification.

\section{Gamma irradiation}

Aqueous solutions of caffeine were irradiated in $200 \mathrm{~mL}$ open pyrex conical flasks without deaeration in a Gammacell 220 type $\gamma$-irradiator with a dose rate of $0.056 \mathrm{kGy} / \mathrm{h}$ in the presence and absence of ozone or hydrogen peroxide. $50 \mathrm{ppm}$ caffeine solutions were ozonized at desired times and irradiated for $0.2 \mathrm{kGy}$ and irradiated in $1.20 \mathrm{mM}$ hydrogen peroxide. The dose rate of the gamma source was detected with the Fricke method at the beginning of the irradiations.

\section{UV - visible spectroscopy}

The absorbance values of unirradiated, irradiated and ozonized $50 \mathrm{ppm}$ caffeine solutions were followed with a Varian Cary 100 model UV-Vis spectrophotometer at the maximum at $272 \mathrm{~nm}$. Formaldehyde tests were examined with a UV-Vis spectrophotometer by recording maximum of complex registered at $412 \mathrm{~nm}$ [28] to see whether the formaldehyde is formed.

\section{$\mathrm{pH}$ measurements}

$\mathrm{pH}$ values of caffeine solutions were measured by an ISTEK NeoMet pH-200L model pH meter.

\section{Ion chromatography}

The determinations of possible aliphatic acids, nitrate and nitrite ions were performed using DX-3000 Ion Chromatography from Dionex, equipped with an electrochemical ultra anion self regenerating suppressor model ASRS $300,4 \mathrm{~mm}$, a conductivity detector set at $50 \mathrm{~mA}$ and an AG9-HC guard column with an analytical column IonPac AS9-HC, columns - Dionex Ionpac AS9-HC $(4 \times 250 \mathrm{~mm})$ and $\mathrm{AG} 9-\mathrm{HC}(4 \times 50 \mathrm{~mm})$ set at $30^{\circ} \mathrm{C}$. Cell heater temperature was $35^{\circ} \mathrm{C}$. The mobile phase was $10 \mathrm{mM} \mathrm{Na} \mathrm{CO}_{3}$ with a flow rate of $1.000 \mathrm{~mL} / \mathrm{min}$ under a pressure of 1800 psi. Samples and standards were injected with an autosampler Dionex AS-3000 as $20 \mu \mathrm{L}$ from vials with a cut segment volume of $10 \mu \mathrm{L}$, the flush volume was $250 \mu \mathrm{L}$ and the syringe speed was 4 .

\section{$\mathrm{GC} / \mathrm{MS}$ analysis}

The ozonized/irradiated caffeine solutions were analyzed with gas chromatography (GC-3900)/mass spectrometry (Saturn 2100T) system with an ion trap mass spectrometer from Varian Instruments (Sunnyvale, CA, USA) operated in the split mode. For chromatographic separation of caffeine and its intermediates (if any), a VF5-MS (30 $\mathrm{m} \times 0.25 \mathrm{~mm}$ i.d.) column with a $0.25 \mu \mathrm{m}$ film thickness was employed. Ion trap mass spectrom- eter was operated in the electron ionization (EI) mode. The NIST library was used to detect possible intermediates, and also our own mass library was created with this program. The mobile phase helium $(99.99 \%)$ was used at a flow-rate of $1 \mathrm{~mL} \cdot \mathrm{min}^{-1}$. Caffeine is characterized by GC/MS by means of retention time and mass spectrum as well as the remaining caffeine was analyzed by following the retention time and mass spectrum.

Standards of caffeine solutions and treated samples collected in vials with dichloromethane after solid phase extraction were injected as $1.0 \mu \mathrm{L}$ manually at a flow rate of $1.0 \mu \mathrm{L} \cdot \mathrm{s}^{-1}$. Mass spectrometer was calibrated weekly and known amounts of caffeine were injected twice a day to validate the calibration curve. Non-resonant wave form was used during analysis. The transfer line, manifold and trap temperatures were 280, 80 and $210^{\circ} \mathrm{C}$, respectively. The analysis was performed with a filament and the multiplier delay was $3.0 \mathrm{~min}$. The automatic gain control (AGC) was activated as an AGC target of 20000 counts. Electrons were generated under $70 \mathrm{eV}$ energy, while the emission current for ionization was set at $10 \mu \mathrm{A}$, and the axial modulation amplitude voltage was $4.0 \mathrm{~V}$.

\section{Extraction of caffeine and possible intermediates}

Varian vacuum manifold system was used for solid phase extraction of caffeine and other possible intermediates from water. Varian octadecyl (C18) one way cartridges, end capped, $10 \mathrm{~mL}$ cartridge volume with $500 \mathrm{mg}$ sorbent were purchased from Varian. The recovery was observed as higher than $90 \%$ for caffeine. Efficiency of the $\mathrm{C} 18$ cartridges were increased by eluting $6 \mathrm{~mL}$ $\mathrm{n}$-hexane, then $12 \mathrm{~mL}$ methanol and $6 \mathrm{~mL}$ HPLC grade water, respectively before sample aspiration. $200 \mathrm{~mL}$ sample was eluted from the conditioned $\mathrm{C} 18$ cartridges with a flow rate of $5 \mathrm{~mL} / \mathrm{min}$ and after sample aspiration, C18 cartridges were dried by purging nitrogen gas for $25 \mathrm{~min}$. Caffeine and other possible intermediates were eluted to vials with $2.0 \mathrm{~mL}$ of dichloromethane.

\section{Derivatization of internal standard 2,4-DP}

2,4-DP samples were dissolved in methanol and acidified with concentrated sulphuric acid for catalyzed esterification. The acidified methanol solution is mixed enough for esterification and $10 \mathrm{~mL}$ of deionized water was added to this solution with sodium chloride to extract 2,4-DP methyl ester into hexane. Then, a desired amount of 2,4-DP methyl ester is prepared in hexane and mixed with caffeine standards and/or extracted samples from C18 cartridges for GC injections.

\section{Ozone generator}

Ozone was generated from atmospheric air by a prototype corona discharge generator (OPAL OGL-20, Turkey) with a production rate of $10 \mathrm{~g} \mathrm{O}_{3} \mathrm{~h}^{-1} .400 \mathrm{ml}$ $50 \mathrm{ppm}$ caffeine solutions were ozonized in a $500 \mathrm{~mL}$ cylindirical pyrex reactor by bubbling the ozone/air mixture through a sinterized glass filter (pore size $50-80 \mathrm{~mm}$ ) 
at various ozonation times which were analyzed directly or transferred to pyrex bottles for irradiation.

\section{Formaldehyde tests}

Formaldehyde tests were performed by the Hantzsch method [28]. The formation of formaldehyde is controlled spectrophotometrically at $\lambda_{\max }=412 \mathrm{~nm}$ by means of a calibration curve.

\section{Determination of total acid yield}

The total acid yield was measured after treatment with the titrimetric method by using $0.01 \mathrm{M} \mathrm{NaOH}$, which is standardized against $0.01 \mathrm{M}$ oxalic acid.

\section{Determination of dissolved oxygen}

WTW Microprocessor Oxi 3000 Oxygen Meter, which includes the membrane-type dissolved oxygen electrodes using a galvanic cell, was used to measure dissolved oxygen. The working electrode uses a noble metal (Ag), and the opposite electrode uses a base metal $(\mathrm{Pb})$.

\section{COD analysis}

Behrotest $^{\circledR}$ TRS 200 model COD instrument with a pyrex bottle set, heater and water bath was used for COD analysis which is based on an open reflux method [29]. After hydrogen peroxide test (iodometric), $50 \mathrm{~mL}$ of samples were transferred in pyrex bottles, heated at $155^{\circ} \mathrm{C}$ for $2 \mathrm{~h}$ with potassium dichromate, sulphuric acid, silver sulphate and mercury(II) sulphate. After cooling, the bottles are filled with water up to $100 \mathrm{~mL}$ and titrated with dilute Mohr salt for the change in ferroin indicator. Blank COD is determined with deionized water as the same procedure. COD value of potassium hydrogen phthalate (KHP) was checked with the same procedure to verify the method and standards.

\section{Results and discussion}

Caffeine, a target compound was irradiated under different conditions, including $1.20 \mathrm{mM}$ hydrogen peroxide concentration, which is the optimum concentration of hydrogen peroxide to be used in this study. The amount of hydrogen peroxide was optimized for various hydrogen peroxide concentrations $(0.6,1.20,1.80$ and $2.40 \mathrm{mM})$ for $50 \mathrm{ppm}$ caffeine solution and $0.5 \mathrm{kGy}$ irradiation dose with a dose rate of $0.056 \mathrm{kGy} / \mathrm{h}$. The amount of hydrogen peroxide lower than $1.20 \mathrm{mM}$ is not enough to degrade caffeine efficiently in water. Similarly, a higher amount of hydrogen peroxide scavenges hydroxyl radicals with a rate constant $k\left(20^{\circ} \mathrm{C}\right)=3.1 \times 10^{10} \mathrm{M}^{-1} \cdot \mathrm{s}^{-1}$. The reactions of hydrogen peroxide in irradiated aqueous solution are [30]

(1) $\mathrm{e}_{\mathrm{aq}}^{-}+\mathrm{H}_{2} \mathrm{O}_{2} \rightarrow{ }^{\circ} \mathrm{OH} \quad k=2.4 \times 10^{10}\left(20^{\circ} \mathrm{C}\right)$
(2) $\mathrm{H}^{\bullet}+\mathrm{H}_{2} \mathrm{O}_{2} \rightarrow{ }^{\bullet} \mathrm{OH}+\mathrm{H}_{2} \mathrm{O} \quad k=1.5 \times 10^{7}\left(20^{\circ} \mathrm{C}\right)$

(3) ${ }^{\bullet} \mathrm{OH}+\mathrm{H}_{2} \mathrm{O}_{2} \rightarrow \mathrm{HO}_{2}^{\bullet}+\mathrm{H}_{2} \mathrm{O} \quad k=3.1 \times 10^{10}\left(20^{\circ} \mathrm{C}\right)$

$$
2 \mathrm{HO}_{2}^{\bullet}+\mathrm{H}_{2} \mathrm{O}_{2} \rightarrow \mathrm{HO}_{2}^{\bullet}+\mathrm{O}
$$

The total effect of the last two reactions are

$$
2^{\bullet} \mathrm{HO}+\mathrm{H}_{2} \mathrm{O}_{2} \rightarrow \mathrm{O}_{2}+2 \mathrm{H}_{2} \mathrm{O}
$$

Reactions in water when exposed to ionizing radiation in the presence of oxygen are the following

(6) $\mathrm{H}_{2} \mathrm{O} \sim{ }^{\cdot} \mathrm{H}, \mathrm{e}_{\mathrm{aq}}^{-},{ }^{\circ} \mathrm{OH}, \mathrm{H}_{2}, \mathrm{H}_{2} \mathrm{O}_{2}, \mathrm{H}_{3} \mathrm{O}^{+}, \mathrm{OH}^{-}[31]$

(7) ${ }^{\bullet} \mathrm{H}+\mathrm{O}_{2} \rightarrow \mathrm{HO}_{2}^{\bullet} k=1.9 \times 10^{10} \mathrm{~L} \cdot \mathrm{mol}^{-1} \cdot \mathrm{s}^{-1}[31,32]$

$$
k=1.2 \times 10^{10} \mathrm{~L} \cdot \mathrm{mol}^{-1} \cdot \mathrm{s}^{-1}
$$

(8) $\mathrm{e}_{\mathrm{aq}}^{-}+\mathrm{O}_{2} \rightarrow \mathrm{O}_{2}^{\bullet-} \quad k=2 \times 10^{10} \mathrm{~L} \cdot \mathrm{mol}^{-1} \cdot \mathrm{s}^{-1}$ $k=1.9 \times 10^{10} \mathrm{~L} \cdot \mathrm{mol}^{-1} \cdot \mathrm{s}^{-1}$

$$
\begin{aligned}
& \mathrm{HO}_{2} \rightleftharpoons \mathrm{H}^{+}+\mathrm{O}_{2}^{\cdot-} \quad \mathrm{pK}=4.8 \\
& \mathrm{HO}_{2}^{\cdot}+\mathrm{O}_{2}^{\cdot-} \rightarrow \mathrm{H}_{2} \mathrm{O}_{2}+\mathrm{O}_{2} \\
& k=1.2 \times 10^{10} \mathrm{~L} \cdot \mathrm{mol}^{-1} \cdot \mathrm{s}^{-1} \\
& k=9.7 \times 10^{7} \mathrm{~L} \cdot \mathrm{mol}^{-1} \cdot \mathrm{s}^{-1}
\end{aligned}
$$

$$
\begin{aligned}
\mathrm{HO}_{2}^{\bullet}+\mathrm{HO}_{2}^{\bullet} \stackrel{2 \mathrm{H}^{+}}{\longrightarrow} \mathrm{H}_{2} \mathrm{O}_{2}+\mathrm{O}_{2} \\
k=3.7 \times 10^{6} \mathrm{~L} \cdot \mathrm{mol}^{-1} \cdot \mathrm{s}^{-1} \\
k=8.3 \times 10^{7} \mathrm{~L} \cdot \mathrm{mol}^{-1} \cdot \mathrm{s}^{-1} \\
\mathrm{O}_{2}^{\cdot-}+\mathrm{O}_{2}^{\bullet-} \stackrel{2 \mathrm{H}^{+}}{\longrightarrow} \mathrm{H}_{2} \mathrm{O}_{2}+\mathrm{O}_{2}^{\bullet} \\
2 k<10 \mathrm{~L} \cdot \mathrm{mol}^{-1} \cdot \mathrm{s}^{-1} \\
2 k=\text { no reaction }
\end{aligned}
$$$$
k=8.3 \times 10^{7} \mathrm{~L} \cdot \mathrm{mol}^{-1} \cdot \mathrm{s}^{-1}
$$

Figure 1 shows the change in UV-Vis spectra of irradiated and unirradiated $50 \mathrm{ppm}$ caffeine solutions and percent decrease in absorbance at $272 \mathrm{~nm}$ [39] with irradiation dose. Hydroxyl radicals from hydrogen peroxide play an important role in the decomposition of caffeine. The absorbance at $272 \mathrm{~nm}$ disappeared completely at a $1.0 \mathrm{kGy}$ irradiation dose in the presence of $1.20 \mathrm{mM} \mathrm{H}_{2} \mathrm{O}_{2}$, although it is at $1.5 \mathrm{kGy}$ without $\mathrm{H}_{2} \mathrm{O}_{2}$. The addition of hydrogen peroxide (finally $1.20 \mathrm{mM}$ ) to unirradiated $50 \mathrm{ppm}$ caffeine solution resulted in a decrease in the absorbance from 2.451 to 2.366 (almost $3.5 \%$ of decrease in absorbance).

Figure 2 shows the change in UV-Vis spectra of ozonized and ozonized/0.2 kGy irradiated $50 \mathrm{ppm}$ caffeine solutions. Absorbance at $272 \mathrm{~nm}$ disappears readily with preliminary ozonation before irradiation since there are two strong hydroxyl radical sources - ozone and gamma irradiation. 0.2 kGy irradiation of ozonized solutions enhances the degradation efficiency of caffeine solutions.

Reactions and rate constants of these reactions of ozone and ozonolysis products in water are investigated by some authors and data are added to the literature [17, 40-42].

Reactions of ozone in irradiated water are:

- Propagation [24]

$$
\mathrm{O}_{3}+\mathrm{O}_{2}^{-} \rightarrow \mathrm{O}_{3}^{-}+\mathrm{O}_{2}
$$



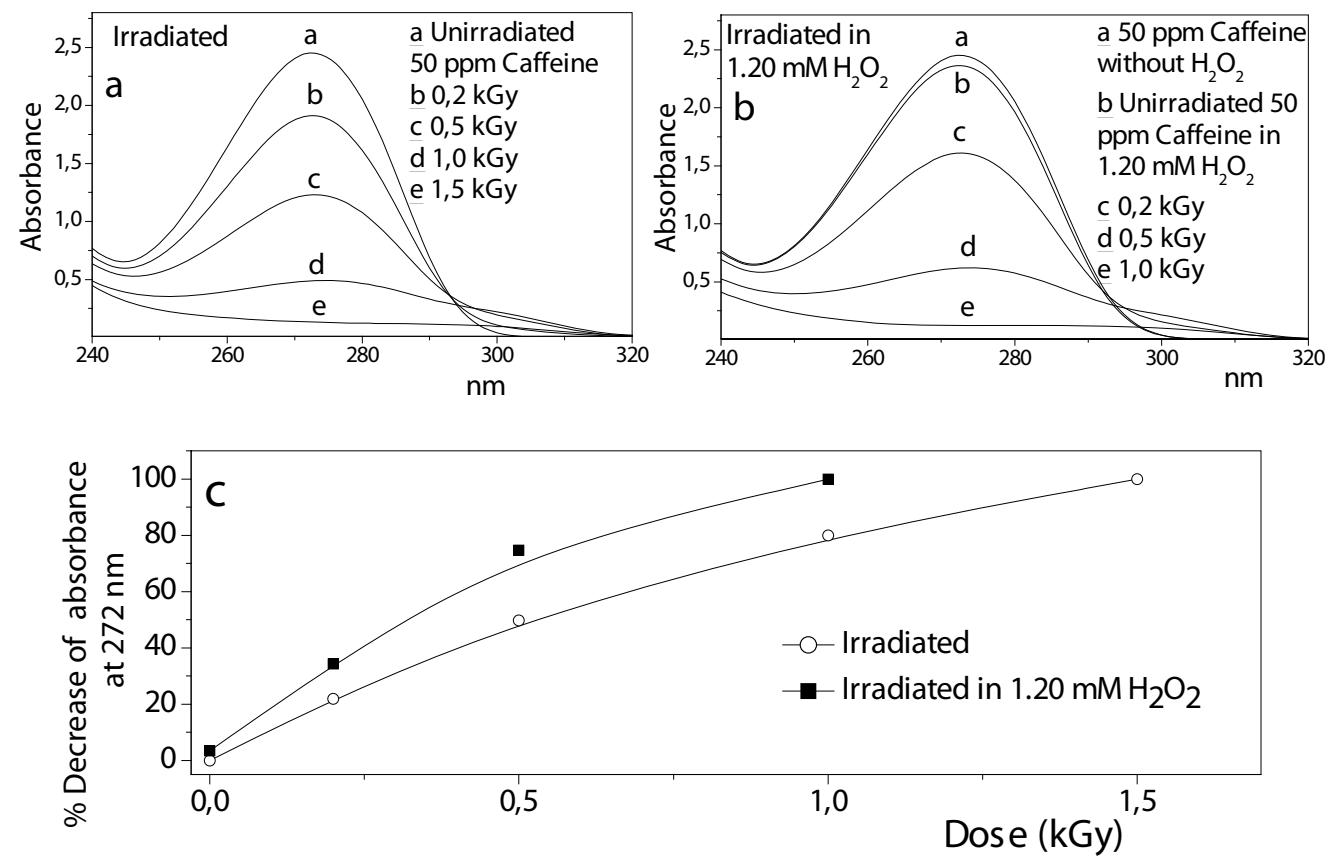

Fig. 1. Variation of the decrease of absorbance of $50 \mathrm{ppm}$ caffeine as a function of irradiation dose at $272 \mathrm{~nm}$ (a) irradiated in free $\mathrm{H}_{2} \mathrm{O}_{2}$, (b) irradiated in $1.20 \mathrm{mM} \mathrm{H}_{2} \mathrm{O}_{2}$; (c) percent decrease in absorbance value.

$$
\begin{gathered}
\mathrm{O}_{3}^{-}+\mathrm{H}^{+} \rightarrow \cdot{ }^{\cdot} \mathrm{OH}+\mathrm{O}_{2} \\
\cdot \mathrm{OH}+\mathrm{O}_{3} \rightarrow \mathrm{HO}_{2}^{\cdot}+\mathrm{O}_{2} \\
\mathrm{HO}_{2}^{\cdot} \rightarrow \mathrm{H}^{+}+\mathrm{O}_{2}^{-}
\end{gathered}
$$

- Termination [24]

(17) $\mathrm{HO}_{2}^{\cdot} \rightarrow \cdot \mathrm{OH} \rightarrow \mathrm{H}_{2} \mathrm{O}+\mathrm{O}_{2}$ (dominant at low pH)

(18) $\quad \cdot \mathrm{OH}+{ }^{\circ} \mathrm{OH} \rightarrow \mathrm{H}_{2} \mathrm{O}_{2}$ (dominant at $\mathrm{pH}>4$ )

UV-Vis spectra of treated caffeine solutions give some information about decomposition of caffeine

for comparison in each condition. The details in degradation of caffeine after treatment were followed by recording with GC/MS analysis. Intermediates after irradiation and/or ozonation could not be detected with GC/MS as well as only degradation of caffeine was followed. The gas chromatogram and mass spectrum of caffeine are given in Fig. 3 with an internal standard (methyl ester of 2,4-DP) for quantitative analysis. In Fig. 3, the most abundant ion in MS spectrum was observed as 194, molecular ion $\left(\mathrm{M}^{+}\right)$of caffeine. The disappearance of isocyanate group $\left(\mathrm{CH}_{3} \mathrm{~N}=\mathrm{C}=\mathrm{O}\right)$ and carbon monoxide $(\mathrm{C}=\mathrm{O})$ gives a new fragmentation product with $\mathrm{m} / \mathrm{z} 109(\mathrm{M}-85)^{+}[43]$. Other fragmentation products, $67(\mathrm{M}-127)^{+}$and $55(\mathrm{M}-139)^{+}$and structures
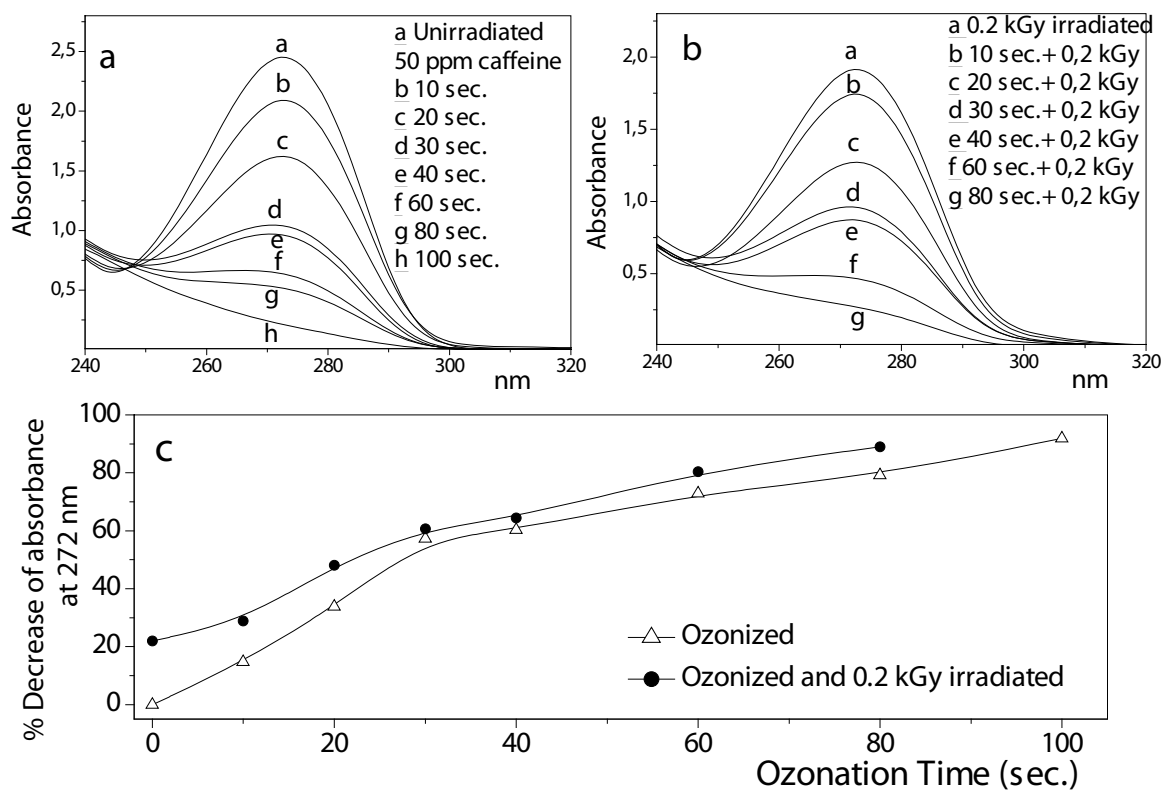

Fig. 2. Variation of the decrease of absorbance of $50 \mathrm{ppm}$ caffeine as a function of ozonation time at $272 \mathrm{~nm}$ (a) ozonized without irradiation, (b) ozonized and irradiated for $0.2 \mathrm{kGy}$; (c) percent decrease in absorbance value. 

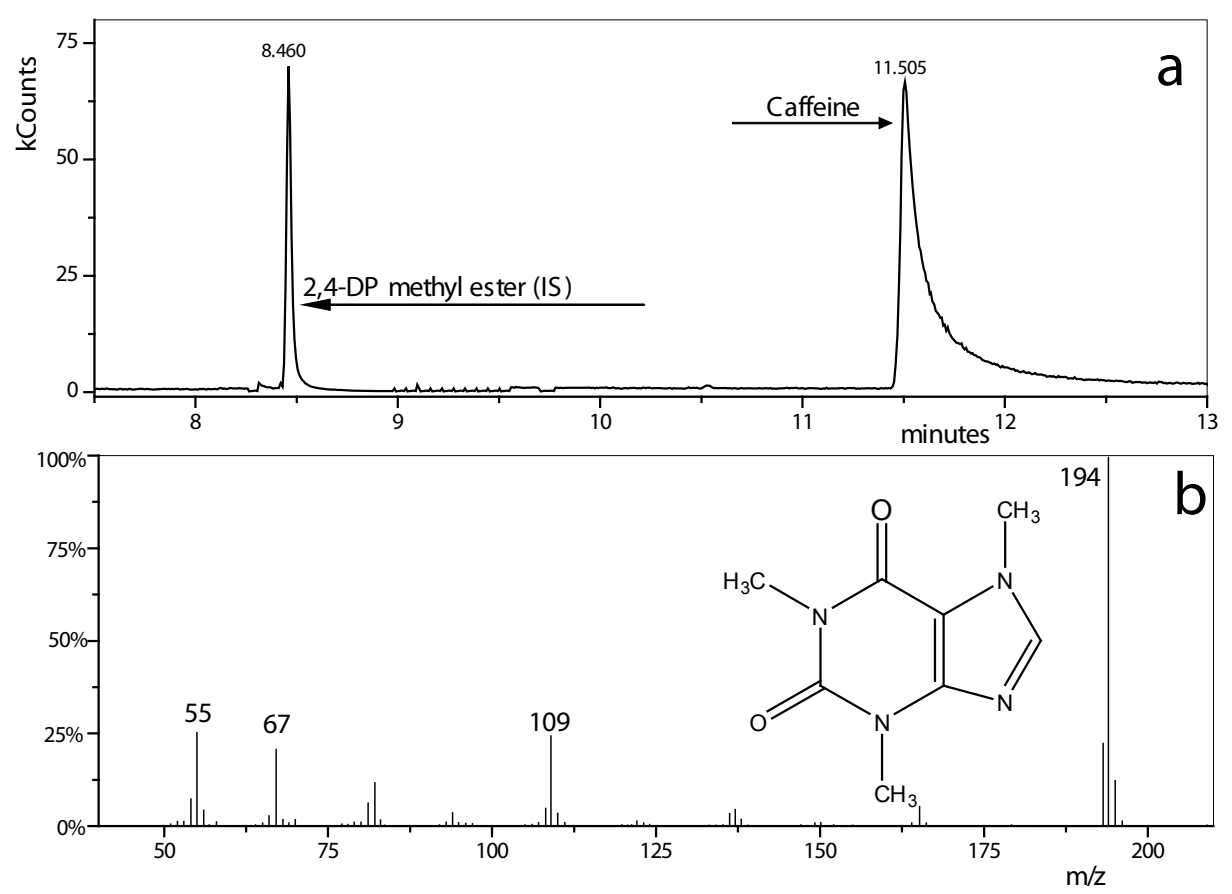

Fig. 3. (a) Gas chromatogram of caffeine ( $25 \mathrm{ppm})$ and 2,4-DP methyl ester as IS (20 ppm), (b) mass spectrum of caffeine.

of these possible fragmentation products are given in Table 1. Figure 4 gives the amount of remaining caffeine for gamma-hydrogen peroxide and gamma-ozone systems. It is clearly observed that the combination of hydrogen peroxide with gamma irradiation and the combination of ozonation with gamma irradiation enhances the degradation of caffeine. $G_{i}$ values are 3.7 and 6.6 for irradiated samples in $\mathrm{H}_{2} \mathrm{O}_{2}$ free and in $1.20 \mathrm{mM} \mathrm{H}_{2} \mathrm{O}_{2}$ solutions, respectively. $G$ values give the efficiency of degradation and the value of $G_{i}$ for samples irradiated in $1.20 \mathrm{mM} \mathrm{H}_{2} \mathrm{O}_{2}$ is nearly two times of only irradiated caffeine. ( $G$ value is the number of molecules decomposed per $100 \mathrm{eV}$ absorbed energy. $G_{i}$ value is the initial $G$ value). $50 \mathrm{ppm}$ caffeine in aqueous solutions were

Table 1. Possible fragmentation products of caffeine in the mass spectrum

$\mathrm{m} / \mathrm{z}$

Fragmentation product or structure

$194\left(\mathrm{M}^{+}\right)$

(Caffeine molecular ion )

$109(\mathrm{M}-85)^{+}$

(Loss of methyl isocyanate group and carbonyl group)<smiles>Cn1c(=O)c2c(ncn2C)n(C)c1=O</smiles><smiles>CNc1cn(C)cn1</smiles>

$67(\mathrm{M}-127)^{+}$<smiles></smiles>

$55(\mathrm{M}-139)^{+}$ decomposed at earlier ozonation times when $0.2 \mathrm{kGy}$ irradiated. $0.2 \mathrm{kGy}$ irradiation of $50 \mathrm{ppm}$ aqueous caffeine solution reduced the ozonation time from 120 to $80 \mathrm{~min}$ to remove caffeine. Spectroscopic results (Fig. 2) supports the effect of gamma irradiation on ozonation. For both results, it is obvious that the combination of these two oxidation processes give a high efficiency for degradation of $50 \mathrm{ppm}$ aqueous caffeine solution. Reactions of caffeine with hydroxyl radical was investigated by electron spin resonance (ESR) spin trapping which reports that caffeine is an effective $\mathrm{OH}$ radical scavenger with a rate constant of $5.9 \times 10^{9} \mathrm{M}^{-1} \cdot \mathrm{s}^{-1}$ [44]. Effective decomposition of caffeine in combined processes rather than only ozonation or gamma irradiation is due to this high rate reaction constant of caffeine with $\mathrm{OH}$ radicals. The addition of $1.20 \mathrm{mM}$ hydrogen peroxide caused the decomposition of nearly $10 \%$ of $50 \mathrm{ppm}$ caffeine without irradiation according to GC/MS results. It is suggested that the oxidation of caffeine by $\mathrm{H}_{2} \mathrm{O}_{2}$ and oxygen free radicals is at the nucleophilic C-8 position of the imidazole ring [45].

Figure 5 gives the change in acidity of caffeine solutions with irradiation and ozonation. Acidity of the solution increases with irradiation and the addition of $1.20 \mathrm{mM} \mathrm{H}_{2} \mathrm{O}_{2}$ increases the total acidity of the solution. The reason for this result is the decomposition of caffeine to weak acidic groups more effectively with additional $\mathrm{OH}$ radicals from $\mathrm{H}_{2} \mathrm{O}_{2}$ [46]. Total acidity of the ozonized samples are increasing with ozonation times, because of oxidation of ozonolysis products, although irradiation of ozonized samples decreases the total acidity of the caffeine solutions. Some researchers detected acidic groups during ozonation of aqueous caffeine [47] as a consequence of the reaction of caffeine with $\mathrm{OH}$ radicals [9]. Irradiation after ozonation can enhance the degradation of formed acids and the total acidity can be reduced. Gamma irradiation of preliminary ozonized caffeine solutions decomposed readily without formation of any major acidic groups. The 

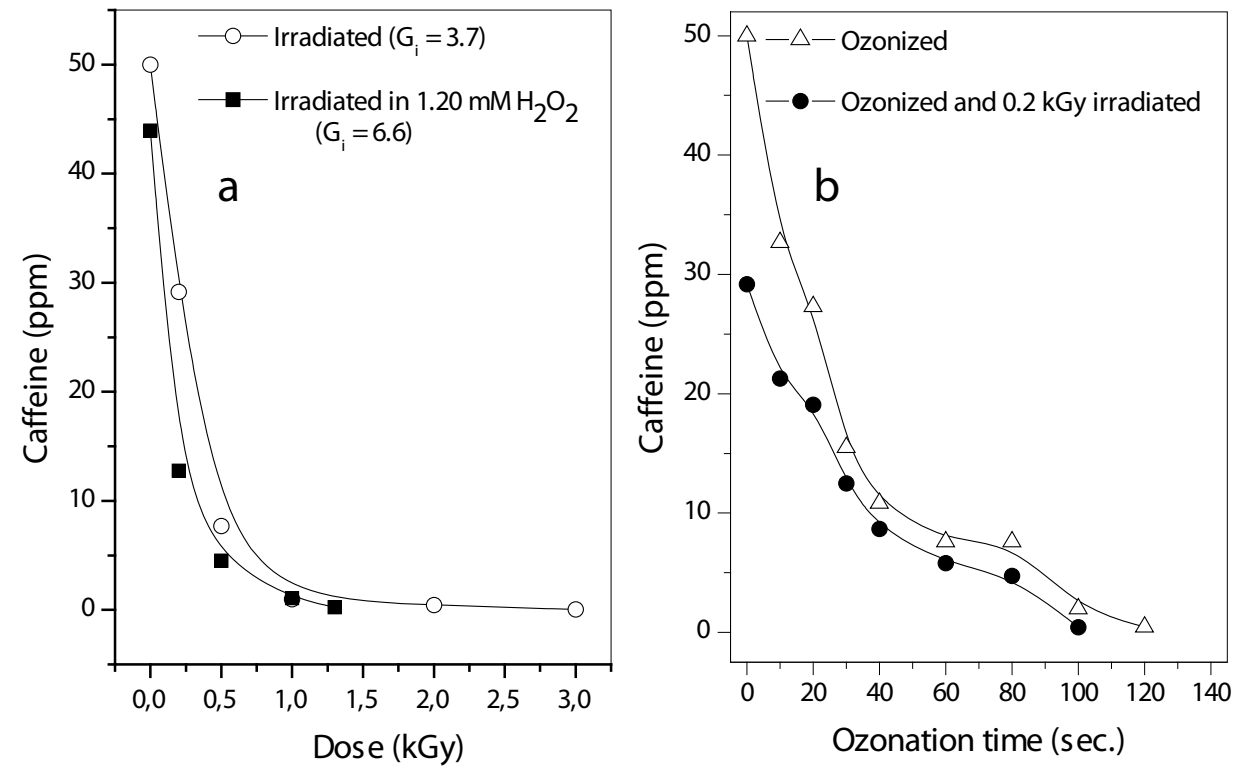

Fig. 4. Change in the amount of remaining caffeine in the treated aqueous samples as a function of (a) irradiation dose and (b) ozonation time. Analytical results were performed by GC/MS.
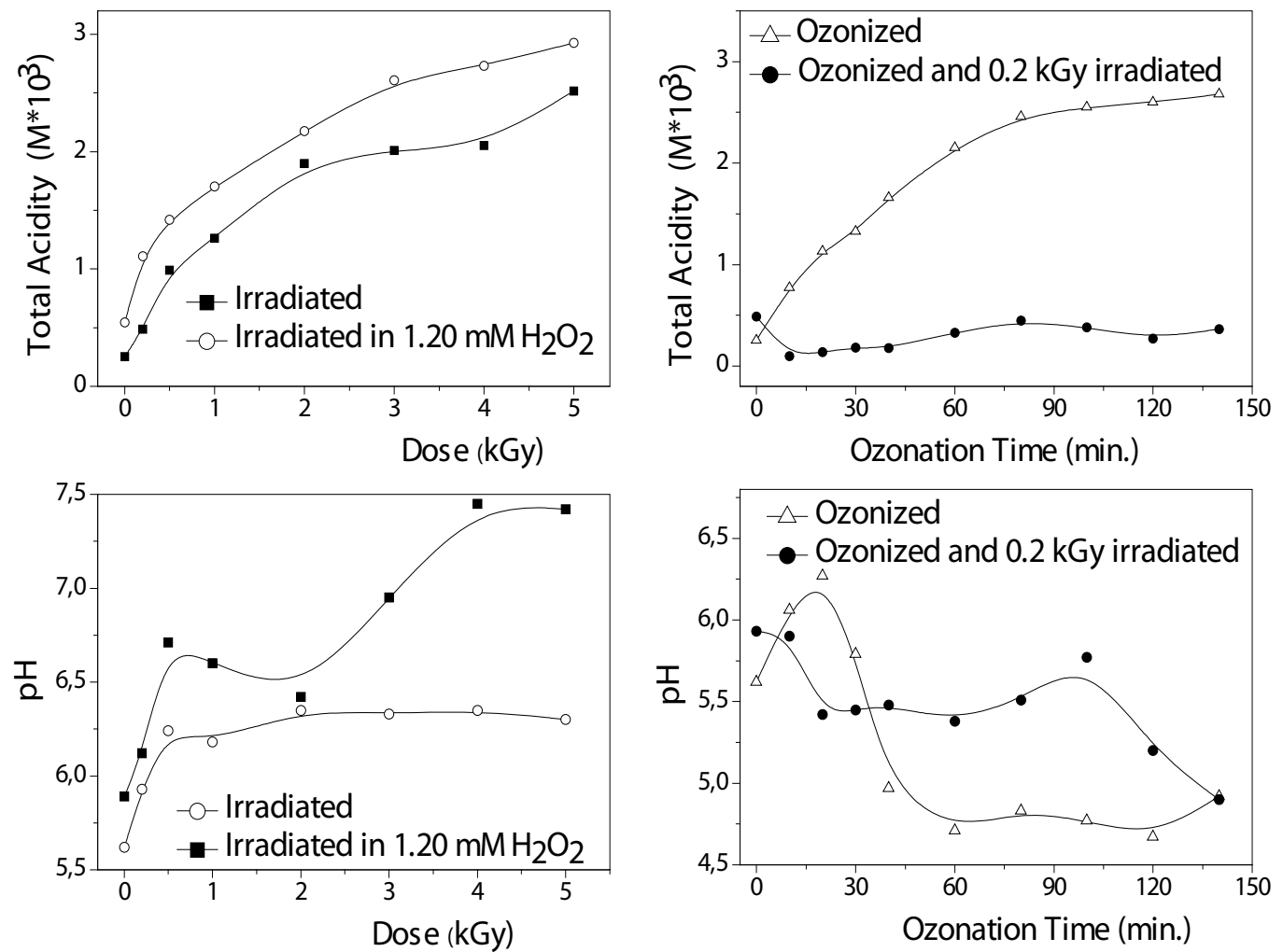

Fig. 5. Change in acidity and $\mathrm{pH}$ of caffeine solution $(50 \mathrm{ppm})$ as a function of irradiation dose and ozonation time.

other effect can be the conversion of possible $\mathrm{NH}_{4}^{+}$ ions to $\mathrm{NH}_{3}$; hydrogen on ammonium ions can react with hydroxyl radicals $\left(\mathrm{NH}_{4}^{+} \ldots \mathrm{OH}\right)$ to form ammonia and water [48]. The other suggestion for acidity with irradiation in the presence of ozone can be due to the formation of less amount of $\mathrm{NH}_{4}^{+}$ions, for only ozonation without irradiation rather than $\mathrm{NH}_{4}^{+}$ions, some weak acids may contribute to acidity. $\mathrm{pH}$ results are not in the trend of total acidity, because of the strength of formed weak acids. Ratio of concentration of $\mathrm{NH}_{4}^{+}$ to concentration of $\mathrm{NH}_{3}$ can affect the $\mathrm{pH}$ value of the solutions.
The amount of dissolved oxygen during irradiation/ ozonation are given in Fig. 6. Dissolved oxygen, one of the important parameter for irradiated aqueous solutions consumed during irradiation and formed during ozonation of samples [49]. $G_{i}$ values of oxygen consumption were found as 1.58 and 0.94 by irradiated in the absence and presence of $1.20 \mathrm{mM} \mathrm{H}_{2} \mathrm{O}_{2}$, respectively. Consumption of oxygen for irradiated $\mathrm{H}_{2} \mathrm{O}_{2}$-free solution was found to be higher with respect to $G_{i}$ values since additional oxygen may be introduced to the solution by decomposition of excess $\mathrm{H}_{2} \mathrm{O}_{2}$ in $1.20 \mathrm{mM} \mathrm{H}_{2} \mathrm{O}_{2}$ solutions. Oxygen-based effective radicals may be consumed more in $\mathrm{H}_{2} \mathrm{O}_{2}$ free 

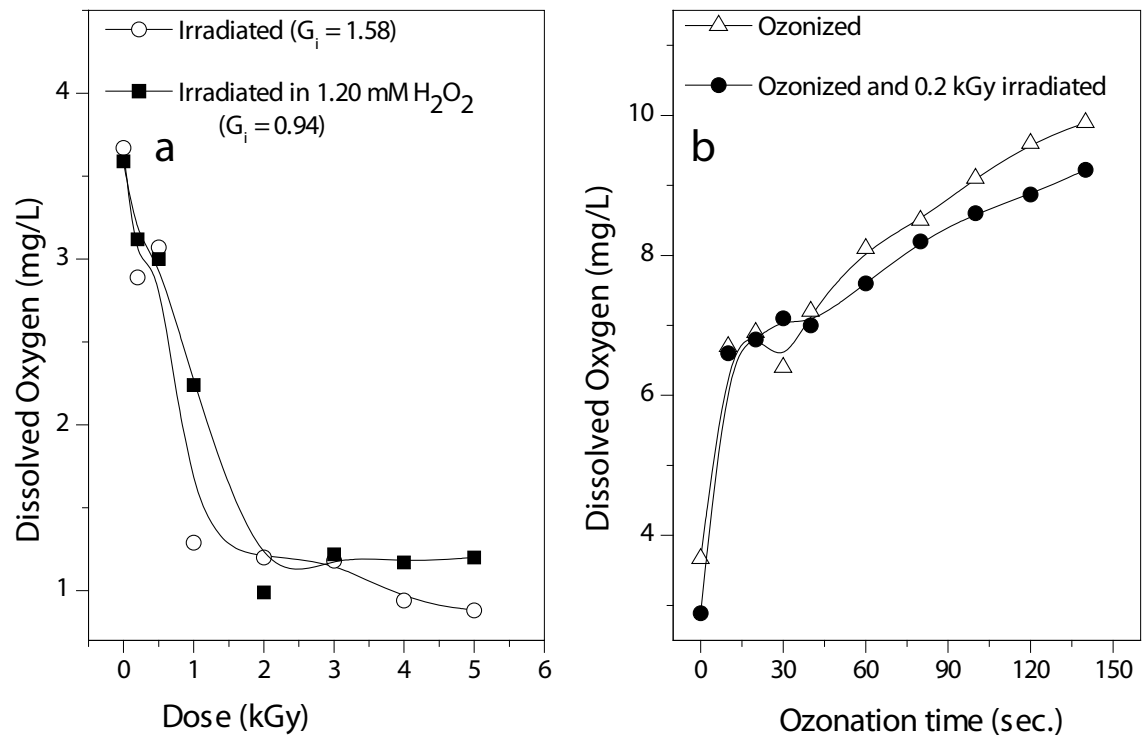

Fig. 6. Change in amounts of dissolved oxygen for caffeine solutions (50 ppm) as a function of (a) irradiation dose and (b) ozonation time.
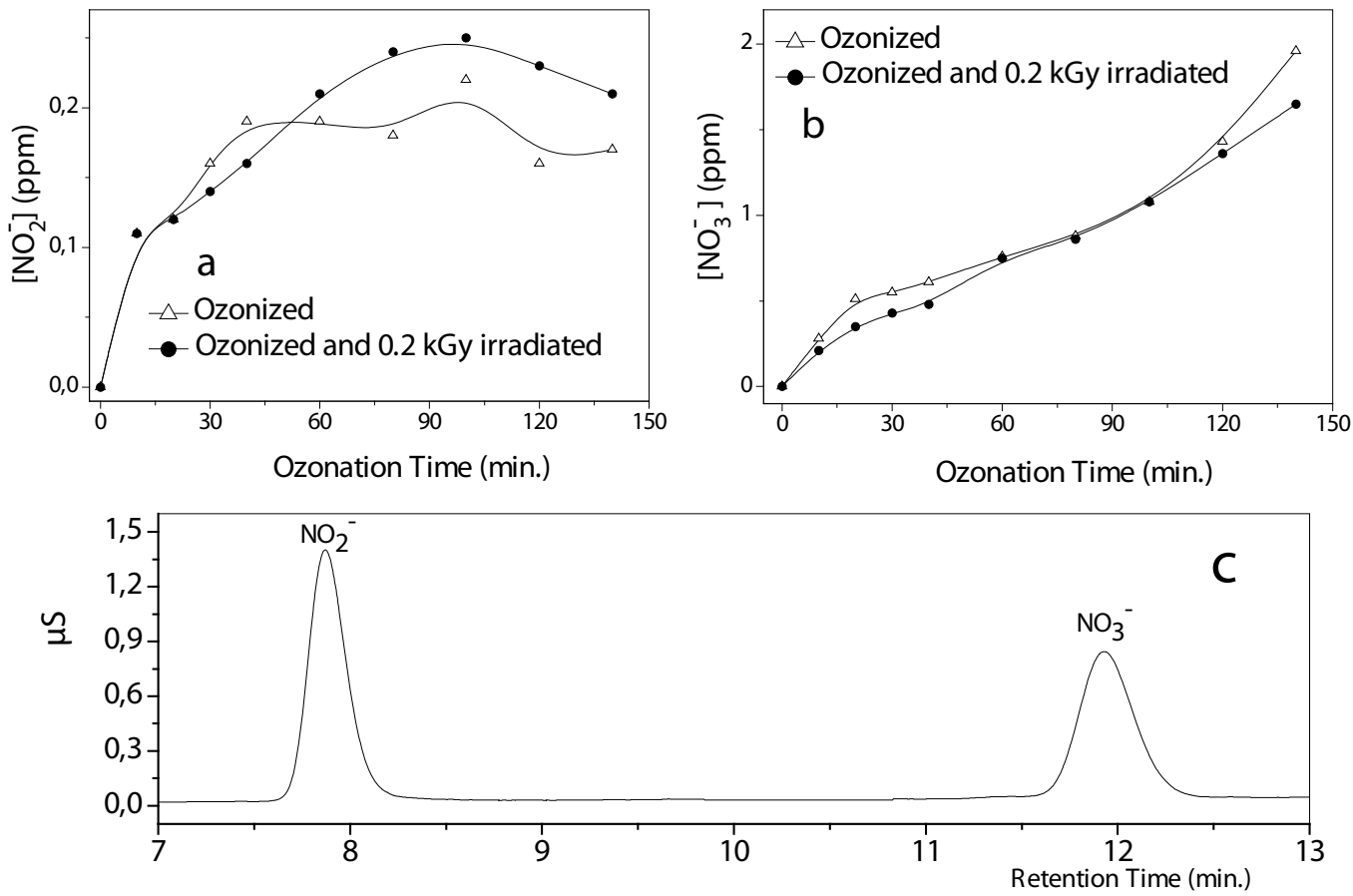

Fig. 7. Changes in the amounts of (a) $\left[\mathrm{NO}_{2}^{-}\right]$and (b) $\left[\mathrm{NO}_{3}^{-}\right]$with ozonation and ozonation/0.2 kGy irradiation dose with an (c) ion chromatogram of $0.5 \mathrm{ppm}$ standard for each of them. Retention times in ion chromatogram are 7870 and $11930 \mathrm{~min}$ for $\left[\mathrm{NO}_{2}^{-}\right]$and $\left[\mathrm{NO}_{3}^{-}\right]$, respectively.

solutions although there is a competition between $\mathrm{OH}$ radicals and oxygen based radicals in solutions irradiated in $\mathrm{H}_{2} \mathrm{O}_{2}$ [30].

Figure 7 gives the amounts of nitrite and nitrate ions formed in ozonized caffeine samples. Retention times of nitrite and nitrate anions were determined by using the standards. Ozonation is a powerful method to oxidize organic and inorganic ions as ammonia and ammonium are readily converted to nitrite and nitrate ions. There is no important difference for the amounts of nitrate ions in ozonized and ozonized/ $0.2 \mathrm{kGy}$ irradiated samples. Nitrite is a possible product of ozonation of ammonia and formed nitrite ions are oxidized to nitrate by ozone [50]. Gamma irradiation alone is environmentally friendly method when compared with ozone since caffeine is decomposed completely without formation of nitrate and toxic nitrite anions.

$$
\begin{gathered}
\mathrm{NH}_{3}+3 \mathrm{O}_{3} \rightarrow \mathrm{NO}_{2}^{-}+3 \mathrm{O}_{2}+\mathrm{H}^{+}+\mathrm{H}_{2} \mathrm{O} \\
\mathrm{NO}_{2}^{-}+\mathrm{O}_{3} \rightarrow \mathrm{NO}_{3}^{-}+\mathrm{O}_{2}
\end{gathered}
$$

Formaldehyde tests for caffeine samples before/after treatment were performed [28] but it is not observed as an intermediate.

Table 2 gives the changes of COD values for caffeine after treatment with gamma, ozone, hydrogen peroxide and synergic effects of ozone and hydrogen peroxide on 
Table 2. Changes in the COD values of $50 \mathrm{ppm}$ aqueous solutions of caffeine with ozonation and irradiation

\begin{tabular}{|c|c|c|c|}
\hline Sample & $\begin{array}{l}\text { COD value } \\
(\mathrm{mg} / \mathrm{L})\end{array}$ & $\begin{array}{c}\text { COD removal } \\
(\%)\end{array}$ & $\begin{array}{c}\text { COD removal (\%) } \\
\text { other than nitrite ions }\end{array}$ \\
\hline 50 ppm caffeine & 46.6 & - & - \\
\hline $0.2 \mathrm{kGy}$ irradiated $50 \mathrm{ppm}$ caffeine & 21.2 & 54.3 & - \\
\hline $3 \mathrm{kGy}$ irradiated 50 ppm caffeine & 12.7 & 72.6 & - \\
\hline 50 ppm caffeine in $1.20 \mathrm{mM} \mathrm{H}_{2} \mathrm{O}_{2}$ & 42.4 & 9.0 & - \\
\hline $1.2 \mathrm{kGy}$ irradiated 50 ppm caffeine in $1.20 \mathrm{mM} \mathrm{H}_{2} \mathrm{O}_{2}$ & 10.6 & 77.3 & - \\
\hline 120 s ozonized 50 ppm caffeine & 8.5 & 81.8 & 81.6 \\
\hline $100 \mathrm{~s}$ ozonized $0.2 \mathrm{kGy}$ irradiated $50 \mathrm{ppm}$ caffeine & 4.2 & 91.0 & 90.7 \\
\hline
\end{tabular}

gamma irradiation. COD value of potassium hydrogen phthalate standard was determined experimentally in the same conditions as samples and compared with its theoretical value. COD values are interfered from inorganic ions such as halides, nitrite and reduced inorganics [29, 51]. Ammonia and ammonium also interferes COD analysis in the presence of chloride ions [29]. In this study, ammonium and ammonia are possible intermediates for irradiated and ozonized samples, nitrate and nitrite ions were the observed intermediates in the presence of ozone for $50 \mathrm{ppm}$ aqueous solutions of caffeine. Some researchers investigated the effect of ammonia/ammonium on the change of COD values and concluded that ammonia/ammonium is not oxidized when chloride is absent [52]. Nitrite ions are also oxidized by consuming potassium dichromate and increase COD by $1.14 \mathrm{mg}$ per mg of nitrite nitrogen [29]. COD analysis based on potassium dichromate does not interfere from ozone because potassium dichromate is not consumed for the oxidation of ozone [53]. Effect of hydrogen peroxide interference on COD measurements were concluded by some authors [53-55] and each of them reported the corrected experimental COD values as a function of hydrogen peroxide concentration. Although hydrogen peroxide is a strong oxidizer, it acts as a reductant if there is a stronger oxidizing agents such as potassium dichromate. If potassium dichromate is added to the hydrogen peroxide solution acidified with sulphuric acid, a green colour acts due to the formation of $\mathrm{Cr}^{3+}$ ions by potassium dichromate reduction [54]. To remove excess hydrogen peroxide that may interfere with COD analysis, samples were hold in an oven for $30 \mathrm{~min}$ at $50^{\circ} \mathrm{C}$ [56] and iodometric tests were followed for residual hydrogen peroxide. It is assumed that heating of the treated caffeine solutions at $50^{\circ} \mathrm{C}$ had no effect on COD values of the samples [57]. Although nitrite ions are one of the degradation products of caffeine that interferes with potassium dichromate, in Table 2, COD recoveries of intermediates other than nitrite ions are given in which the contribution of nitrite ions to COD data are very low. It is clearly observed that ozonation is a powerful method for the COD removal. For $100 \mathrm{~s}$ ozonized/0.2 kGy irradiated $50 \mathrm{ppm}$ aqueous solution of caffeine, the highest removal of COD values were observed. This may be attributed to the mineralization of caffeine to carbon dioxide, water and ammonia [43] in the presence of ozone. Change in total acidity in Fig. 5 correlates this suggestion, the total acidity increases with ozonation although ozonation combined with irradiation causes the total acidity to be almost constant. This suggests that only ozonation still oxidizes some intermediates although ozonation/irradiation performed mineralization with a yield of more than 90\%. COD removal increases with irradiation dose and irradiation in $1.20 \mathrm{mM}$ hydrogen peroxide enhances the COD removal. An addition of $1.20 \mathrm{mM} \mathrm{H}_{2} \mathrm{O}_{2}$ to $50 \mathrm{ppm}$ caffeine solution caused a COD removal of $9.0 \%$, which is consistent with the decomposition of nearly $10 \mathrm{ppm}$ caffeine in the presence of $1.20 \mathrm{mM}$ hydrogen peroxide. Observation of nitrite and nitrate ions in the presence of ozone is compatible with COD removal values since the presence of these ions are the explanation of mineralization.

\section{Conclusion}

Caffeine is one of the important water contaminant existing in water naturally or artificially. Some chemical methods under advanced oxidation processes were performed to remove caffeine from water, but there is not much attention to use gamma irradiation in a part of advanced oxidation processes. In this study, AOPs that include gamma irradiation was performed and caffeine is completely decomposed with high energy radiation and ozonation. Some parameters were followed such as total acidity, $\mathrm{pH}$, nitrite-nitrate anions, dissolved oxygen, COD changes and the determined results were discussed above. The retention times of some aliphatic acids were indicated by using ion chromatography and formaldehyde tests were performed by using a UV-Vis spectrophotometer, for any possibility, all treated caffeine samples were investigated for aliphatic acids and formaldehyde, but none of them were observed. Effect of hydrogen peroxide on irradiation and irradiation on ozonation was investigated for $50 \mathrm{ppm}$ aqueous solution of caffeine both with UV-Vis and GC/MS. It is observed that irradiation in hydrogen peroxide and irradiation after ozonation enhances the degradation of caffeine. Total acidity of the $50 \mathrm{ppm}$ aqueous solution of caffeine increased with irradiation and ozonation although there is no change with ozonation/irradiation. Consumption of oxygen, used for radiolysis reactions, was observed with the change of irradiation dose. Nitrite and nitrate anions, which are the last steps for degradation of caffeine were detected only for ozonized and ozonized/irradiated samples. Gammairradiation is environmentally suitable method for the decomposition of caffeine because there is no formation of nitrate and toxic nitrite ions during treatment. COD results showed decomposition of $50 \mathrm{ppm}$ aqueous solution of caffeine to its intermediates with a yield of more than $70 \%$ when all caffeine is decomposed. Mineralization in the presence of ozone is more effective since COD removals are more than $80 \%$ with an 
observation of nitrite and nitrate ions with ion chromatography. Irradiation of $50 \mathrm{ppm}$ aqueous solution of caffeine in the presence of $1.20 \mathrm{mM}$ hydrogen peroxide also increased the COD removal (\%) values.

Acknowledgment. D. Abbasova acknowledges the financial support of the International Atomic Energy Agency under C6-AZB08005 project number to carry out the experiments in the Laboratories for Radiation and Polymer Science, Hacettepe University, Ankara, Turkey. This work was performed at the Hacettepe University Department of Chemistry, Ankara, Turkey.

\section{References}

1. Martin, M. J., Pablos, F., \& Gonzalez, A. G. (1998) Discrimination between arabica and robusta green coffee varieties according to their chemical composition. Talanta, 46, 1259-1264.

2. Silvarolla, M. B., Mazzafera, P., \& de Lina, M. M. A. (2000). Caffeine content of Ethiopian Caffea Arabica beans. Genet. Mol. Biol., 23, 213-218.

3. Barber, L. B., Leenheer, J. A., Pereira, W. E., Noyes, T. L., Brown, G. K., Tabor, C. F., \& Writer, J. H. (1995) Organic compounds and sewage-derived contaminants. In R. H. Meade (Ed.) Contaminants in the Mississippi River 1987-1992 (pp. 115-135). US Geological Survey Circular 1133. Virginia.

4. Paxeus, N., \& Schröder, H. F. (1996). Screening for nonregulated organic compounds in municipal wastewater in Göteborg, Sweden. Water Sci. Technol., 33, 9-15.

5. Seiler, R. L., Zaugg, S. D., Thomas, J. M., Howard, D. L. (1999). Caffeine and pharmaceuticals as indicators of wastewater contamination in wells. Ground Water, 37, 405-410.

6. Pandey, A., Soccol, C. R., Nigam, P., Brand, D., Mohan, R., \& Roussos, S. (2000). Biotechnological potential of coffee pulp and coffee husk for bioprocesses. Biochem. Eng. J., 6, 153-162.

7. Rojas, J. B. U., Verreth, J. A. J., Amato, S., \& Huisman, E. S. (2003). Biological treatments affect the chemical composition of coffee pulp. Bioresour. Technol., 89, 267-274.

8. Landolt, H. P., Dijk, D. J., Gauss, S. E., \& Borbely, A. A. (1995). Caffeine reduces low-frequency delta activity in the human sleep EEG. Neuropsychopharmacology, 12, 229-238.

9. Shilo, L., Sabbah, H., Hadari, R., Kovatz, S., Weinberg, U., Dolev, S., Dagan, Y., \& Shenkman, L. (2002). The effects of coffee consumption on sleep and melatonin sectretion. Sleep Med., 3, 271-273.

10. Gokulakrishnan, S., Chandraraj, K., Sathyanarayana, N., \& Gummadi, N. (2005). Microbial and enzymatic methods for the removal of caffeine. Enzyme Microb. Technol., 37, 225-232.

11. Udayasankar, K., Raghavan, C. V., Rao, P. N. S., Rao, K. L., Kuppuswamy, S., \& Ramanathan, P. K. (1983). Studies on the extraction of caffeine from coffee beans. J. Food Sci. Technol.-Mysore, 20, 64-67.

12. Cesaro, A., Rosso, E., \& Crescenzl, V. (1976). Thermodynamics of caffeine. J. Phys. Chem., 80(3), 335-339.

13. Gehringer, P., Proksch, E., Eschweiler, H., \& Szinovatz, W. (1992). Remediation of groundwater polluted with chlorinated ethylenes by ozone-electron beam irradiation treatment. Appl. Radiat. Isot., 43(9), 1107-1115.

14. Getoff, N. (1996). Radiation induced degradation of water pollutants-state of the art. Radiat. Phys. Chem., 47(4), 581-593.
15. Lichtscheidl, J., \& Getoff, N. (1976). Radiolysis of halogenated aromatic compounds in aqueous solutions-I conductometric pulse radiolysis and steady-state studies of the reaction of $\mathrm{e}_{\text {aq }}^{-}$. Int. J. Radiat. Phys. Chem., 8(6), 661-665.

16. Lin, K., Cooper, W. J., Nickelsen, M. G., Kurucz, C. N., \& Waite, T. D. (1995). Decomposition of aqueous solutions of phenol using high energy electron beam irradiation. A large scale study. Appl. Radiat. Isot., 46(12), 1307-1316.

17. Wang, T., Waite, T. D., Kurucz, C., \& Cooper, W. J. (1994). Oxidant reduction and biodegradability improvement of paper mill effluent by irradiation. Water Res., 28(1), 237-241.

18. Getoff, N. (1989). Advancements of radiation induced degradation of pollutatnts in drinking and waste water. Appl. Radiat. Isot., 40(7), 585-594.

19. Glaze, W. H., Weinberg, H. S., Krasner, S. W., \& Sclimenti, M. J. (1991) Trends in aldehyde formation and removal through plants using ozonation and biological active filters. In Proceedings of the Conference AWWAAC-Water Quality for the New Decade, 22-27 June 1991 (pp. 913-943). Philadelphia.

20. Getoff, N. (1997). Peroxyl radicals in the treatment of waste solutions. In Z. B. Alfassi (Ed.), Peroxyl radicals. (pp. 173-234). Chichester: Wiley.

21. Hoigné, J., \& Bader, H. (1983). Rate constants of reaction of ozone with organic and inorganic compounds in water-I non-dissociating organic compounds. Water Res., 17(12), 173-183.

22. Rice, R. (1996). Applications of ozone for industrial wastewater treatment. A review. Ozone-Sci. Eng., 18(6), 477-515.

23. Yao, C. C. D., \& Haag, W. R. (1991). Rate constants for direct reactions of ozone with several drinking water contaminants. Water Res., 25(7), 761-773.

24. Hart, E. J., Sehested, K., Bjergbakke, E., \& Holcman, J. (1987). Gamma-ray initiated decomposition of aqueous ozone solution. Radiat. Phys. Chem., 29, 399-403.

25. Hoigné, J. (1998). Chemistry of aqueous ozone and transformation of pollutants by ozonation and advanced oxidation processes. In The Handbook of Environmental Chemistry (Vol. 5, Part C, pp. 83-141). Berlin: Springer.

26. Sehested, K., Holcman, J., \& Hart, E. J. (1983). Rate constants and products of the reactions of $\mathrm{e}^{-}{ }_{\mathrm{aq}}, \mathrm{O}_{2}{ }^{--}$, and $\mathrm{H}$ with ozone in aqueous solutions. J. Phys. Chem., 87, 1951-1954.

27. Moore, M. T., Greenway, S. L., Farris, J. L., \& Guerra, B. (2008). Assessing caffeine as an emerging environmental concern using conventional approaches. Arch. Environ. Contam. Toxicol., 54, 31-35.

28. Nash, T. (1973). The colorometric estimation of formaldehyde by means of the Hantzsch method. J. Biochem., 55, 416-421.

29. American Public Health Association. (1997). Standard methods for the examination of water and wastewater. 5220B Chemical oxygen demand open reflux method. (20th ed.). Washington DC.

30. Christensen, H., Sehested, K., \& Løgager, T. (1994). Temperature dependence of the rate constant for reactions of hydrated electrons with $\mathrm{H}, \mathrm{OH}$ and $\mathrm{H}_{2} \mathrm{O}_{2}$. Radiat. Phys. Chem., 43, 527-531.

31. Sanchez, M., Wolfger, H., \& Getoff, N. (2002). Radiation-induced degradation of 4-chloroaniline in aqueous solution. Radiat. Phys. Chem., 65(6), 611-620.

32. Anbar, M., Farhataziz, \& Ross, A. B. (1975). Selected specific rates of reactions of transients from water in aqueous solution. II. Hydrogen atom. (National Standard Reference Data Series). Washington: US National Bureau of Standards. 
33. Buxton, G. V., Greenstock, C. L., Helman, W. P., \& Ross, A. B. (1988). Critical review of rate constants for reactions of hydrated electrons, hydrogen atoms, hydroxyl radicals in aqueous solutions. J. Phys. Chem. Ref. Data, 17, 533-538.

34. Anbar, M., Bambenek, M., \& Ross, A. B. (1973). Selected specific rates of reactions of transients from water in aqueous solution. I. Hydrated electron. (National Standard Reference Data Series. NSRDS-NBS 43). Washington: US National Bureau of Standards.

35. Bielski, B. H. J., Cabelli, D. E., Arudi, R. L., \& Ross, A. B. (1985). Reactivity of $\mathrm{HO}_{2} / \mathrm{O}_{2}^{-}$radicals in aqueous solution. J. Phys. Chem. Ref. Data, 14(4), 1041-1100.

36. Getoff, N., \& Prucha, M. Z. (1983). Spectroscopic and kinetic characteristics of $\mathrm{HO}_{2}$ and $\mathrm{O}_{2}^{-}$species studied by pulse radiolysis. Naturforscher., 3, 589-590.

37. Bielski, B. H. J., \& Cabelli, D. E. (1991). Review: highlights of current research involving superoxide and perhydroxyl radicals in aqueous solutions. Int. J. Radiat. Biol., 59, 291-319.

38. Cabelli, D. E. (1997). The reactions of $\mathrm{HO}_{2}{ }^{\circ} / \mathrm{O}_{2}{ }^{-}$radicals in aqueous solutions. In Z. B. Alfassi (Ed.), Peroxyl radicals. (pp. 407-437). Chichester: Wiley.

39. Belay, A., Ture, K., Redi, M., \& Asfaw, A. (2008). Measurement of caffeine in coffee beans with UV/vis spectrometer. Food Chem., 108, 310-315.

40. Bühler, R. E., Staehelin, J., \& Hoigne, J. (1984). Ozone decomposition in water studied by pulse radiolysis. 1 . $\mathrm{HO}_{2} / \mathrm{O}_{2}^{-}$and $\mathrm{HO}_{3} / \mathrm{O}_{3}{ }^{-}$as intermediates. J. Phys. Chem., $88,2560-2564$.

41. Steahelin, J., Bühler, R. E., \& Hoigne, J. (1984). Ozone decomposition in water studied by pulse radiolysis 2 . $\mathrm{OH}$ and $\mathrm{HO}_{4}$ as chain intermediates. J. Phys. Chem., 88, 5999-6004.

42. Tomiyasu, H., Fukutomi, H., \& Gordon, G. (1985). Kinetics and mechanism of ozone decomposition by basic aqueous solution. Inorg. Chem., 24, 2962-2966.

43. Liguori, A., Mascaro, P., Porcelli, B., Sindona, G., \& Uccella, N. (1991). Identification of caffeine and its metabolites in human urine extracts by electron impact ionization tandem mass spectrometry. J. Mass Spectrom., 26(6), 608-612.

44. Shi, X., \& Dalal, N. S. (1991). Antioxidant behaviour of caffeine: efficient scavengers of hydroxyl radicals. Food Chem. Toxicol., 29(1), 1-6.

45. Stadler, R. H., Richoz, J., Turesky, R. J., Wielti, D. H., \& Fay, L. B. (1996). Oxidation of caffeine and related methylx- anthines in ascorbate and polyphenol-driven Fenton-type oxidations. Free Radic. Res., 24(3), 225-240.

46. Telo, J. P., Vieira, \& A. J. S. C. (1997). Mechanism of free radical oxidation of caffeine in aqueous solution.J. Chem. Soc. Perkin Trans. 2, 9, 1755-1757.

47. Kolonko, K. J., Shapiro, R. H., Barkley, R. M., \& Sievers, R. E. (1979). Ozonation of caffeine in aqueous solution. J. Org. Chem., 44(22), 3769-3778.

48. Dalmazio, I., Santos, L. S., Lopes, R. P., Eberlin, M. N., \& Augusti, R. (2005). Advanced oxidation of caffeine in water: on-line and real-time monitoring by electrospray mass spectrometry. Environ. Sci. Technol., 39, 5982-5988.

49. Torun, M., Şolpan, D., \& Güven, O. (2011). Treatment of water contaminated with chlorinated organic herbicide 2,4-D by an ozone/gamma process. Ozone-Sci. Eng., 33(1), 50-65.

50. Yang, M., Uesugi, K., \& Myoga, H. (1999). Ammonia removal in bubble column by ozonation in the presence of bromide. Water Res., 33(8), 1911-1917.

51. Bauman, F. J. (1974). Dichromate reflux chemical oxygen demand, a proposed method for chloride correction in highly saline wastes. Anal. Chem., 46, 1336-1338.

52. Kim, B. R. (1989). Effect of ammonia on COD analysis. Journal of the Water Pollution Control Federation, 61(5), 614-617.

53. Lee, E., Lee, H., Kim, Y. K., Sohn, K., \& Lee, K. (2011). Hydrogen peroxide interference in chemical oxygen demand during ozone based advanced oxidation of anaerobically digested livestock wastewater. Int. J. Environ. Sci. Technol., 8(2), 381-388.

54. Kang, Y. W., Cho, M. J., \& Hwang, K. Y. (1999). Correction of hydrogen peroxide interference on standard chemical oxygen demand test. Water Res., 33(5), 1247-1251.

55. Zak, S. (2008). Problem of correction of the chemical oxygen demand values determined in wastewaters treated by methods with hydrogen peroxide. Proceedings of ECOpole, 2(2), 409-414.

56. Pala, A., \& Erden, G. (2005). Decolorization of a baker's yeast industry effluent by Fenton oxidation. J. Hazard. Mater., B127, 141-148.

57. Martinez, N. S. S., Fernandez, J. F., Segura, X. F., \& Ferrer, A. S. (2003). Pre-oxidation of an extremely polluted industrial wastewater by the Fenton's reagent. J. Hazard. Mater., B101, 315-322. 